University of Nebraska - Lincoln

DigitalCommons@University of Nebraska - Lincoln

Journal for the Advancement of Developing

Economies

Economics Department

2014

European Union and African Union: A Study of Regionalism for

Global Integration and Development

Soji Oyeranmi

University of South Africa

Follow this and additional works at: https://digitalcommons.unl.edu/jade

Part of the Econometrics Commons, Growth and Development Commons, International Economics Commons, Political Economy Commons, Public Economics Commons, and the Regional Economics Commons

Oyeranmi, Soji, "European Union and African Union: A Study of Regionalism for Global Integration and Development" (2014). Journal for the Advancement of Developing Economies. 8.

https://digitalcommons.unl.edu/jade/8

This Article is brought to you for free and open access by the Economics Department at DigitalCommons@University of Nebraska - Lincoln. It has been accepted for inclusion in Journal for the Advancement of Developing Economies by an authorized administrator of DigitalCommons@University of Nebraska - Lincoln. 


\title{
European Union and African Union: A Study of Regionalism for Global Integration and Development
}

\author{
Soji Oyeranmi \\ University of South Africa
}

\begin{abstract}
Scholars of international political economy have made remarkable inroad into the study of comparative integration endeavors across the globe. For examples, over the last few years, comparative studies of the North Atlantic Free Trade Area (NAFTA) and the European Union (EU) had been undertaken to reveal the factors that facilitated the success of each organization in their integration efforts at the regional level. Also, a comparative study of the Asia Pacific Economic Cooperation (APEC) and the European Union has also been undertaken. However, very little effort has been made to reveal the impact or power of regionalism on African development. Enough scholarly attention has not also been given to the latent but eloquent influence of the European Union on the African Union to demonstrate how regional integration and interregional cooperation could promote or hinder African development and global integration. It is in order to fill this lacuna that this work focuses primarily on the role of regionalism in the entrenchment or otherwise of regional integration, good governance and African development through an in-depth comparative study of the European Union (EU) and the African Union (AU).
\end{abstract}

\section{INTRODUCTION}

According to Bourke (2003), the study of comparative integration efforts has been quite fashionable for scholars of international political economy. It is in line with this that experts like Babarinde (2007) Oyugi (2009) and Olukoshi (2009) in the past decade, have undertaken comparative studies of the North Atlantic Free Trade Area (NAFTA) and the European Union (EU) to reveal the factors that facilitated the success of each organization in their integration efforts at the regional level. Also, a comparative study of the Asia Pacific Economic Cooperation (APEC) and the European Union has also been undertaken (Lachapelle \& Trent, 2002). However, very little effort has been made to reveal the impact or power of regionalism on African development. Neither was enough scholarly attention given to the latent but eloquent influence of the European Union on the African Union to bring out the necessity or otherwise of "Regionalism beyond regions"; as it enhances or debars the much-touted regional integration and development in the era of surging globalization.

Against this background, this work focuses primarily on the role of regionalism in the entrenchment or otherwise of regional integration, good governance and African development through an in-depth comparative study of the European Union (EU) and the African Union (AU). The factors responsible for the successes and challenges of the European Union in its integration efforts and the attempt to globalize it through its operations in Africa on one hand; and the very modest and limited success of the African Union (with or without inspiration from EU) on the other hand will be examined before a conclusion is drawn on whether or the not this inter regional cooperation is 
serving (or could serve) any purpose in the much debated roles regionalism is playing on African development in the era globalization.

The 21st Century with the upsurge of the phenomenon of globalization was anticipated with great hope by all especially the crippled arms of humanity in the Third World Countries particularly in Africa. On the surface, globalization as a process seems to enhance interdependence of people, through the constant and mutual exchange of goods, services and information within and across the borders of countries. Boost in global economic interchange, wide spread political cooperation and increasing global social relations thus become natural outcomes of the phenomenon of globalization. To the proponents of the new economic order such as Hoogvelt (1997), globalization will bring more development to the underdeveloped countries by increasing the efficiency in industries, competitiveness, and speedy growth of the economy in general through the mutually beneficial North -South relations. But as the 21 st Century grows old, the roads to attain most of the old promises are getting narrower. Not only that the vast majority of humanity in the global South (especially in Africa) is still groaning under heavy economic burden and socio-political dislocations but the global cooperation and integration (in tackling these problems) had largely remained an illusion (Aina, 1996, Amin, 1972, 1976 \&Ake, 1992, 2002).

But what form of international order is globalization inaugurating? Has it generated or even capable of generating a "New World Order,"? Is globalization more than an economic phenomenon? Is there any link between regionalism and global integration in this era? What is the role of the European Union within and without Europe? Is the Euro-African relation a necessity? Could it be a European pill to correct the ills of the past? Or is it a new form of exploitation in the name of integration? Who gains what? Who influences who? Could this neo North-South relation really contribute meaningfully to global integration and universal develop/governance which still lies ahead? Several theories have been proposed and espoused on globalization and its operations to provide answers to most of these critical questions.

\section{REGIONALISMS FOR INTEGRATION IN ERA GLOBALIZATION: A THEORETICAL EXPOSITION}

Several theories have been espoused on globalization. For example, Alexandra Barany (2010) categorized theories on globalization in to four. These include: The World-Economy theory or Hyperglobalisationism (which sees globalization as a process by which capitalist world-system spreads across the entire globe so much that global marketplace has become so advanced and integrated at the expense of the nation-state that is becoming obsolete); the Regional Bloc Theory or Global Skepticism (which strongly disagrees with hyper globalists. Though it recognizes the existence of single world market, but it argues that the growing internationalization of trade and investment is really as a result of the growth of regional economic blocs such as the European Union); the Third Way Theory or Transformationalism(which Seeks to find a relationship between economic processes occurring at the global and local scales, known as transformationalism view because it looks for ways of transforming the powers of the nation-state to cope with pressures of globalization); The World-Culture Theory or Homogenism (desires to preserve and celebrate difference against cultural homogenization, it defers from all other theories because it sees globalization more broadly, being the increasing uniformity of cultures across the world, instead of just from an economic perspective ). 
In the study by Sigler (2011), the traditional Western compartmentalization of human life into four areas - politics, economics, culture, and religion - has given rise to four possible paradigms in explaining the phenomenon of globalization. This includes: the political approach with its optimistic and pessimistic perspectives. The global political optimists such as Fukuyama (1992) sees globalization as truly a harbinger of universalization of the world where there will be: "Open borders, open trade and most importantly, open minds; a world that celebrates the common heritage that belongs to the entire world's people, taking pride not just in hometown or homeland but in humanity itself" (p.48).

The political pessimistic paradigm was engineered by Farid Zakaria, Robert D. Kaplan, and Samuel Huntington. To them: "globalization had divided humanity into a privileged class of people that $L e$ Monde had termed a "cosmocracy" (who were boarding planes bound from Seoul, Hong Kong, Singapore, and Tokyo) and a marginalized class of downtrodden souls" (Huntington, 1996).

The economic approach is most prevalent view of globalization. The economists see it in terms of increased economic interdependence and the integration of all national economies into one economy within the framework of a capitalist market (Frank, 1993).

According to John Sigler, (2010), the third response (Cultural approach) to the challenge of globalization is rather critical. The main thesis is that for globalization to achieve its ends, world of cultures or intermingling of culture must be embraced. It argues that Karl Marx predicted the coming of this new world in, for example, the following passage from The Communist Manifesto:

"All fixed fast-frozen relations, with their train of ancient venerable prejudices and opinions are swept away, all newly formed ones become antiquated before they can ossify. All that is solid melts into air all that is holy is profaned, and man is at last compelled to face with sober senses, his real conditions of life, and his relations with his kind. The need of constantly expanding market for its products chases the bourgeoisie over the whole surface of the globe. It must nestle everywhere, settle everywhere, and establish connections everywhere." (Sigler, 2010, p20).

Cultural approach which was equally rooted in the philosophy of Karl Jaspers (1976) argued that what the world desperately needed was a universal philosophy when he predicted "we are on the road from the evening-glow of European philosophy to the dawn of world philosophy"

The fourth response to the new world comes from radical-minded individuals and groups of both religious and secular kinds who have also taken a position vis-à-vis globalization (Held and McGrew, 1997, Griffin \& Khan,1992). There seems to be no end in sight to the discussion about the possible role of globalization in the creation of new world order. But this study is primarily interested in digging out the relevance of regionalism in global integration and development using the relatively novel EU -AU relations to do justice to the scholarly discourse.

\section{THE EUROPEAN UNION AS A MODEL OF REGIONALISM: PROSPECTS AND PROBLEMS}

Several reasons have been adduced by integration theorists to promote regionalism which include: the desire to maintain peace and peaceful co-existence; the need for multipurpose capabilities; and 
the need for capacity building (Haas, 1971). There are several forms of integration which covers: Politics, Security and Economy. On the political scene, we have examples such as the defunct Organization of African Unity (OAU) which is now African Union (AU); the defunct League of Nations; the United Nations among others. On the Security front, we have Organizations such as NATO, the Organization for Security and Cooperation in Europe (OSCE) etc. In the Economic arena, we have bodies like ECOWAS, the North American Free Trade Area (NAFTA), The West African Economic and Monetary Union, the European Common Market (ECM) the European Union (EU, which is our focus here) just to mention a few (Coleman et-al, 2004).

The European Union has a long and impressive history. Its evolution dated back to the 1950s when six foundational Nations of Belgium, France, former West Germany, Italy, Luxembourg and the Netherlands came together to create a common market for coal, iron and steel product under the auspices of European Coal and Steel Community (Craig, 1970). According to a 2007 publication by the European Union Commission, they created a new way of coming together to manage their joint interests based essentially on economic integration. The "original six" were joined by Denmark, Ireland and the United Kingdom in 1973; Greece in 1981; Spain and Portugal in 1986; Germany in 1990 after the unification; Austria, Finland and Sweden in 1995 (The European Communities, 2007). It must also be mentioned that the expansion which EU is enjoying today was actually precipitated by the 1992 Maastricht treaty which promoted new forms cooperation among national governments by given more responsibilities to the Community. Today, the EU has grown from mere Six to a conglomeration of twenty-seven-member states and further expansion is still a great expectation as the Union moves on.

The unprecedented devastation brought to humanity as a whole and Europe particularly by the Second World War and the inescapable impetus for rebuilding of Europe in the aftermath the war also greatly influenced the necessity for integration of the hitherto dislocated entity. The World War II was the largest and most destructive in human history, with 60 million dead across the world; more than 40 million people in Europe had died as a result of the war by the time war ended, including between 11 and 17 million people who perished during the Holocaust (Niewyk, 2000). The Soviet Union lost around 27 million people during the war, about half of all World War II casualties and by the end of World War II, Europe had more than 40 million refugees (BBC News, 2005).

From all indications, the European Union represents a 'big model' and a success story of regionalism or regional integration derivable from certain explicit and inexplicable reasons. First and foremost is the entrenched and historical essence shared by most European Nations which aided the integration processes. This is why it has been argued that the idea of European Unity is never a new phenomenon. For example, there was a measure of unity during the time Roman Empire especially during the reign of Charlemagne and later under Napoleon I but such cases, unity was achieved based on force and conquest (AWAKE!, 2000). The Cultural and Scientific Revolutions also boosted the further cooperation and integration of Europe.

The Renaissance (which initiated the Cultural Revolution) was a period of cultural change originating in Florence and later spreading to the rest of Europe in the 14th century. The rise of a new humanism was accompanied by the recovery of forgotten classical Greek and Arabic knowledge from monastic libraries, often re-translated from Arabic into Latin (Rourke, 2003). As 
reflected in the opinion of Jacob Burckhardt, the Renaissance spread across Europe between the 14th and 16th centuries: "it saw the flowering of art, philosophy, music, and the sciences, under the joint patronage of royalty, the nobility, the Roman Catholic Church, and an emerging merchant class" (Burckhardt, 1990). Patrons in Italy, including the Medici family of Florentine bankers and the Popes in Rome, funded prolific quattrocento and cinquecento artists such as Raphael, Michelangelo, and Leonardo da Vinci. Evidently, since the Renaissance, Europe has had a major influence in culture, economics and social movements in the world (Levey, 1971). The most significant inventions had their origins in the Western world, primarily Europe and the United States.

Age of Discovery, a period of exploration, invention, and scientific development also greatly entrenched possibility of integration in Europe. Among the great figures of the Western scientific revolution of the 16th and 17th centuries were Copernicus, Kepler, Galileo, and Isaac Newton. According to Peter Barrett: "It is widely accepted that 'modern science' arose in the Europe of the 17 th century (towards the end of the Renaissance), introducing a new understanding of the natural world" (Barrett, 2004).

In the 15th century, Portugal and Spain, two of the greatest naval powers of the time, took the lead in exploring the world. Christopher Columbus reached the New World in 1492, and soon after the Spanish and Portuguese began establishing colonial empires in the Americas. France, the Netherlands and England soon followed in building large colonial empires with vast holdings in Africa, the Americas, and Asia. It was this colonial adventure that set historical background for the EU-AU relations which is the focus of this essay.

Europe and EU are also deriving remarkable from immigration. According to a recent report by the International Office of Migration (IOM), Europe is home to the highest number of migrants of all global regions at 70.6 million people. In 2005, the EU had an overall net gain from immigration of 1.8 million people, despite having one of the highest population densities in the world (Migration Information Source, 2005). This accounted for almost 85\% of Europe's total population growth and The European Union has also opened job centers for legal migrant workers from Africa (BBC News, 2007). In 2008, 696,000 persons were given citizenship of a EU27 member state, a decrease from 707,000 the previous year (The Daily Express, 2009). Largest groups that acquired citizenship of an EU member state were citizens of Morocco, Turkey, Ecuador, Algeria and Iraq (Eurostat, 2010).

The magnificent economic prowess of Europe and EU has proven to be the most decisive factor in the integration drive. As a continent, the economy of Europe is currently the largest on Earth and it is the richest region as measured by assets under management with over $\$ 32.7$ trillion compared to North America's \$27.1 trillion in 2008 (Fineman, 2009). In 2009 Europe remained the wealthiest region. Its $\$ 37.1$ trillion in assets under management represented one-third of the world's wealth (Fineman, 2009). It was one of several regions where wealth surpassed its pre- crisis yearend peak with other continents. Europe has a large variation of wealth among its countries. The European Union, an intergovernmental body composed of 27 European states, comprises the largest single economic area in the world (Scott, 2005). 16 EU countries share the euro as a common currency. Five European countries rank in the top ten of the world's largest national economies in GDP (PPP) which includes: Germany (5), the UK (6), Russia (7), France (8), and Italy (10) (The CIA World Factbook, 2008). 
With the above background, it is therefore not surprising that EU has recorded many remarkable successes. Some of the achievements will be discussed here. According to EU Commission in 2009, the EU succeeded in paving way for economic recovery after the global economic recession in Europe by mobilizing huge resources towards revamping the European Economies. In doing this, countries such as Greece, Spain, Portugal and Italy have received billions as bailouts out of their catastrophic economic downturn/meltdown; economic recovery plans would be a mirage without effective communication among the citizens of the member States. This is why the EU has also invested remarkably on mobile phones to ensure easy and cheap communications among the citizenry; also, to promote the fundamental principle of the Union which is the promotion of economic cooperation and development, the EU has created single currency (Euro) and single market for the benefit of the citizens as well as companies and by ensuring that customers receive fair deals from their banks (BBC News, 2012). 'Health is wealth' to ensure a healthy community, the EU has continued to invest huge amounts on 'new science and new medicines' which are meant to tackle diseases such as dementia; In order to tackle the menace of climate change the EU is also making frantic efforts on ensuring safe and clean environment across the Community; rapid response to disasters in Europe has also been institutionalized within the framework of the European Union.

However, in spite of the aforementioned laudable accomplishments, the EU is not free from some excruciating difficulties. Some of these include: the EU is confronting serious dilemma of expanding the membership and this hindering its real progress. This is further compounded by the conflict between supra-nationalism and inter-governmentalism due to the reluctance of many national governments to cede control of overall policy areas to EU Institutions despite their must touted acceptance of supranationalism-especially in the areas of foreign policy and judicial matters. Securing the long-term success of Euro is also creating serious challenge the financial structures of the body after the expansion. Most importantly, there seems to be serious anxiety about the future of EU as many European Nations continue showing serious concern about the possibility of losing the ability to act independently especially in the area of security (NATO). This suspicion has continued to generate a lot of criticisms directing towards the fear that the EU is becoming more undemocratic and that "the EU would no longer be the servant of the member states, it would have become their master." These criticisms and challenges notwithstanding, EU is unlikely to disappear. In fact, EU has not only become a fact of life in the continental Europe but has moved beyond the region by establishing relations with other regions of the World such as the EuropeAfrica Relations as exemplified by the connections between the European Union and African Union which is the focus of this research.

\section{AFRICAN UNION: A BRIEF BACKGROUND, PROSPECTS AND PROBLEMS}

Africa's flirtation with the concept of African Union in form of a pan-African economic and political integration is not a recent development. Certainly, as some scholars have contended "regional integration schemes are not a postcolonial phenomenon in Africa at both the continental and sub-continental levels" (Ojo, Omo\& Zlete, 1985). The idea is actually traceable to the turn of the 20th Century with the formation of the Southern African Custom Union (SACU) in 1910 which remains the oldest functioning manifestation of regional integration in Africa. Among the most notable contemporary examples are: Arab Maghreb Union (AMU) founded in 1989; East African 
Community (EAC), which was initially founded in 1967 but disbanded in 1977 and revived again in 1994; The Economic Community of West African States (ECOWAS),comprising 16 countries was founded in 1975 ; The Economic Community of Central African States (ECCAS) that links 11 countries was set up in 1983; Common Market For Eastern and Southern African(COMESA) that encompasses 19 African countries came on board in 1993; The Southern African Development Community (SADC) was also founded in 1993 and so on (African Union,2006).

Meanwhile, the real idea of all-encompassing African regionalism which initiated the Pan- African cooperation Community dated back to the eve of Africa's independence. According to the African Union website, this could be attributed to emergence of several pan-African groups such as the one that gathered in Manchester City to promote freedom, justice, equity and economic welfare of the African people. This aspiration culminated in the formation of the Organization of African Unity (OAU) on May 25, 1963, essentially with the comprehensive calls for African unity by most notable pan-Africanists such as Julius Nyerere of Tanzania, Kwame Nkrumah of Ghana, Marcus Garvey and many more (Nkrumah,1963).

Taking a clue from the above historical foundations and apparent ineffectiveness of the existing regionalism in Africa, OAU transformed itself to the African Union (AU) in 2002. With inspiration from the European Union and the urgent need to restructure the operations of the regional arrangements, African leaders under the late Libyan leader Muammar Ghadafi inaugurated the African Union comprising 53 members with the exception of Morocco. The Sirte declaration on September 9, 1999 (named after Sirte in Libya-the home of Ghadafi), was followed by summits in Lomé in 2000, when the Constitutive Act of AU was adopted, and in Lusaka in 2001, when the plan for implementation of African Union was also adopted (African Union.2006). During the same period, the initiative for the establishment of the New Partnership for African Development (NEPAD) was also established (Nevin, 2001:10-13). The African Union was eventually launched on the 9th of July 2002, in Durban, South Africa with Thabo Mbeki-the then South African President as the first Chairperson (Taylor, 2005).

As reflected in the thought of Franklyn Lisk (2010), the AU has clearly had reasonable successes through its direct contribution and collaboration with the international community to settling and minimizing conflicts in some of the region's hotbeds, such as trouble spots in the Sudan, resolving post-election violent conflicts in Cote d'Ivoire and Kenya, and forcing military coup- makers to hand back power to civilian regimes. As a remarkable departure from the largely insensitive doctrine of 'non-interference' in the internal affairs of member states of the OAU, the AU has the authority through decisions of its Peace and Security Council to interfere in member states to promote peace and protect democracy, including deploying military force in situations in which genocide and crimes against humanity are being committed. The AU's first military intervention in a member state was the May 2003 deployment of a peacekeeping force of soldiers from South Africa, Ethiopia, and Mozambique to Burundi to oversee the implementation of the various agreements (Cilliers, 2008). AU troops were also deployed in Sudan for peacekeeping in the Darfur conflict, before the mission was handed over to the United Nations on 1 January 2008 UNAMID. The AU has also sent a peacekeeping mission to Somalia, of which the peacekeeping troops are from Uganda and Burundi (Cilliers, 2008). 
As published on the Union's web site, the AU has also adopted a number of important new documents establishing norms at continental level, to supplement those already in force when it was created. These include the African Union Convention on Preventing and Combating Corruption (2003), the African Charter on Democracy, Elections and Governance (2007), and the New Partnership for Africa's Development (NEPAD) and its associated Declaration on Democracy, Political, Economic and Corporate Governance. This has led to the emergence of AU's unique voluntary 'Peer Review Mechanism' by which individual member states agree to be assessed by a team of experts drawn from other states is designed to encourage democracy and good governance. AU observer missions are now sent as a matter of routine to cover elections in all member states, in accordance with the African Charter on Democracy, Elections and Governance (2007). Judging from the drastic fall in conflicts and coups, and the increasing number of successful elections in the region in the past decade, it can be inferred that on balance actions by the AU has added value to Africa's 'political performance' (Lisk, 2010).

Furthermore, in pursuit of prosperity in the region, the AU has put in place declarations and institutions to promote and support economic integration among its 54-member states as the pathway to sustainable development. Progress has been made by the AU commission, in collaboration with international partners and the UN, towards better coordinating and harmonizing development policies and programs with the five Regional Economic Communities (RECs) representing the various geographical regions of the continent. Some of these RECs, such as the Economic Community of West African States (ECOWAS), the East African Community (EAC) and the Southern Africa Development Community (SADC), have been quite active in exploring possibilities to harmonize budgetary and fiscal policies and for a monetary union on the basis of a common currency. Proposals for an African central bank and an African monetary union at the continental level are still on the drawing board, as vested interest and concerns about sovereignty hold back the necessary political will to drive the process.

In spite of the limited achievements recorded so far, The AU faces many challenges which have made some critics regarded the body as a mere talking shop or mere caricature of the EU. One of the most difficult crisis confronting the leaders in AU is how to respond to the job and livelihood aspirations of Africa's youths who account for as much as three-quarters of the labor force in most countries; many have gone to school and attended universities to become productive members of society, but end up being jobless. High and still rising levels of unemployment among young people in Africa prompted heads of state at the AU summit in Malabo, Equatorial Guinea, last June to adopt a 'Declaration on Creating Employment for Accelerating Youth Development and Empowerment.' The AU rightly recognizes the demographic dividend to be reaped from the region's youthful population structure, as numerous countries in Asia have benefited from over the past two decades, and, hence, member states are encouraged to link their growth performance and development pattern to the creation of employment and socio-economic opportunities especially for young people (Rugumamu, 2005).

Other problems include: health issues such as combating malaria and the AIDS/HIV epidemic; political issues such as confronting undemocratic regimes and mediating in the many civil wars; economic issues such as improving the standard of living of millions of impoverished, uneducated Africans; ecological issues such as dealing with recurring famines, desertification, and lack of ecological sustainability; as well as the legal issues regarding Western Sahara and many more. 
Despite numerous protocols and signing of technical consensus documents to facilitate the free movement of goods and people across borders, the AU's record in stimulating the removal of trade barriers between countries in the union is less than impressive and the value of intra-African trade is still abysmally low as a percentage of total trade.

From all indications, the AU more than ever before now pays serious attention to international development cooperation and relationship with international partners in order to tackle some the above-mentioned challenges. China's ever-growing presence in Africa and very close tie with the Union clearly comes to mind. Although the recent Chinese gift of 200 million Dollars headquarters of the AU in Addis Ababa has continued to generate obvious concerns/skepticisms above the motive and outcome from the West and Africans; both the Organization and China see it as "partnership entering new era of hope" (Wang, 2012). But for Africa and Africans to accrue maximum benefit from this 'new found Chinese love' and even from the EU: The Regional body would have to adopt an appropriate strategy to manage international cooperation in an era of globalization and in a changing world order. It would need to come up with a relevant and practical conceptualization of 'innovative and transformative partnership', which its member states would certainly need, to complement national development efforts (Lisk, 2010). Perhaps, being more creative by $\mathrm{AU}$ and African countries relationships with other regional bodies such as EU and drawing positive inspiration from them could also assist greatly in making AU impact more meaningfully on the lives of average Africans.

\section{CRITICAL EVALUATION OF EU-AU RELATIONS IN THE ERA GLOBALIZATION}

What is the nature of the 'international order' that globalization intends to inaugurate? Has it generated or even capable of generating a "New World Order,"? Is there any link between regionalism and global integration in this era? What is the role of the European Union within and without Europe? Is the Euro-African relation a necessity? In an attempt to provide answers to the above and other related questions, this study shall adopt the Regional Bloc Theory which recognizes the existence of single world market but argues that the growing internationalization of trade and investment is really as a result of the growth of regional economic blocs such as the European Union) and integrative approach which seeks to revive and combine the four approaches to the study of globalization (political, economic, cultural and religious) in understanding the human condition even in the era globalization. The integrative approach will offer a tremendous opportunity in having a holistic study of EU-AU relations towards understanding the nexus between regionalism and globalism.

The issues bothering on Euro-Africa relations through the European Union and African Union have enjoyed a considerable amount of attention from observers and analysts of international relations, scholars and writers alike. Though, only few of them have really compared the two directly, however, their write-ups have neither ignored the comparisons. For example, Babarinde (2007) analyses the AU and its Constitute Act, also discusses the limits of the comparison between the AU and its European counterpart. He also examines the impulses for change from the Organization of African Unity to the African Union. He moves further by analyzing the different roads to the founding of the African Union - Togo, Sitre Libya and concluded that there is no nexus between the European Union and African Union. 
In an in-depth analysis of European Union relations with developing world, Brown (2002) offered a critical evaluation of Lomé Convention, which contained the principles upon which all relations between the States of the European Union and ACP (African, Caribbean and Pacific) countries are based. Apart from this, the Lomé Agreement was also presented as of one of the most important agreements in the recent history guiding the EU-developing world relations. As a historical study, the author examined over twenty-five years existence of the Convention, which has successfully altered the changing relationship of those states involved. This study not only projects on how to open a new vista in the vital relationship between wealthy and poor nations; but also offers ways to change focus, shift concerns and bring about broader positive changes at the global level in the international relations in favor of vast majority of poor nations of the world-especially those in Africa.

Walter Oyugi (2009) in his contribution offers a comparative analysis of African Union and European Union. He inter -alia examines the remarkable attempts by Africa's political leadership to promote regional integration as a means of fast-tracking economic progress, facilitating peace and security, consolidating democratic gains, and promoting the general welfare of the general welfare of the African people. He also examines the transition of the Organisation of African Unity (OAU) to the African Union (AU), as well as the fostering of a new economic blueprint for the continent - The New Partnership for Africa Development (NEPAD). Oyugi argues further that the impetus of a regional development strategy was largely retarded by the slow pace of economic progress on the continent and as a result of the increased marginalization of Africa the global economy. He concludes that, in order for AU live up to the expectations of most Africans, the body must learn from the EU experience.

But scholars, international relations experts and diplomats are sharply divided over the necessity for this Euro-Africa relation. While some are very optimistic about the possibility of Africa to be better off, many are so cynically pessimistic about any positive outcome for the Africans. The need for the promotion of EU-AU relations could be primarily seen as the fulfillment of the age long theory or belief in the unflinching interdependence of humanity across races or regions which is one of the fundamental principles of globalization. In a vivid consonance with this.

Jim Garrinson (1995) submitted that

"Human interdependence must now become our watchword, as we move into the global civilization which lies ahead; interdependence with each other, interdependence with the Earth, and interdependence with the Spirit which perennially guides the affairs of humankind".

In share display of absolute faith in the creation of the New World Order though the inter- regional cooperation and support for the UN system of regional control, the United States acted as the first major non-African country to appoint a full-time ambassador to the African Union (AU) in 2009.This according to the U.S. ambassador to the African Union, Michael Battle was to demonstrate "the importance the people of the United States attach to their partnership with the people of Africa". President Obama and the then Secretary of State, Hillary Rodham Clinton have long seen Africa 'as having the capacity to function with a single voice on continent-wide issues', like the European Union acts as a single voice on issues that affect Europe. 
But it was Zbigniew Brzezinski, a die-hard globalist, who provided the most fundamental inspiration for this study by directly linked regionalism with globalism. He not only strongly advocated for strong links between regional supra-national bodies such as the EU and AU, but indeed sees regionalism as the most powerful tool for global integration. In his opinion: "We cannot leap into world government in one quick step...The precondition for...genuine globalization is progressive regionalization, because thereby we move toward larger, more stable, more cooperative units" (Brzezinski,1995). This sentiment was also re-echoed during the AfricaEU Summit held in Tripoli in November 2010 by the European Commission President José Manuel Barroso, who quoted an old African proverb to illustrate the spirit of the Joint Africa-EU Strategy: "If you want to go fast, walk alone. But if you want to go far, walk together with others."

The adoption of a Joint Africa-EU Strategy (JAES) at the summit held in Lisbon in December 2007 seemed to the most concrete positive step towards creating mutually beneficial EU-Africa relations (Africa-EU Joint Strategy, 2007). The JAES is an ambitious operational framework to ensure full ownership by the various stakeholders in both Africa and Europe. The JAES is said to possess the potential to overcome the traditional donor-recipient relationship that for too long has dominated the Euro-African partnership. The joint strategy could also serve to reinforce political dialogue at a continental level on all key areas of common interest to Africa and Europe. The issue of peace and security, for instance, has been singled out by both parties as a positive example of where the two continents have a common interest and where so far Africa has laid down clear objectives and a roadmap. The EU has been a major supporter of Africa-led peacekeeping as well as capacity development in the area of peace and security for the African Union Commission and the continent's regional economic communities (RECs). The EU has also made commitments to improve its funding mechanisms to support the African Union's role as a mediator during crisis situations in Africa, including in situations of unconstitutional change. These promising initiatives build on the existing or emerging pan-African architectures on peace and security, as well as governance (Round, 2007).

Africa and Europe are also trying to explore new areas of common interest and cooperation such as climate change, energy and science, information society and space. At the institutional level new mechanisms have been put in place to broaden and intensify the dialogue between the two regions, including the regular Commission-to-Commission meetings, EU-Africa Troika Ministerial and technical expert's meetings. Also, the reinforced EU Delegation to the African Union (AU) in Addis Ababa has boosted political dialogue.

But with the adoption of a Joint Africa-EU Strategy (JAES) since 2007, as Barroso observed, can one really say Africa and Europe are indeed 'walking together', let alone "going far? "Indeed, the EU-Africa relationship is facing a number of excruciating challenges which have led to wide spread pessimism in Europe and deep cynicism in both regions. For example, it has been argued that while the EU is still a major investor, trade partner and provider of development assistance in Africa, it appears to be rapidly losing ground on the continent. This was clearly illustrated by the fact that the November 2010 Africa-EU Summit in Tripoli hardly made it into the headlines on either of the two continents. Even Brussels-based diplomatic representatives from African countries complained about the lack of information and the failure to involve them in preparation for the summit. 
Very often the rapid rise of new emerging powers such as China, India, Brazil and the Arab world is perceived as the single most important factor for the declining EU influence in Africa (Wang, 2012). But the reasons for this should also be found closer to home in the "internal kitchen" of the EU and in the quickly fading illusion that the partnership can be driven mostly by the two commissions through institutional and rather technocratic approaches. The EU is confronted with a major leadership and credibility gap in its relationship with Africa. In spite of the promising but complex Lisbon Treaty with the newly created functions of President of the European Council and the High Representative for Foreign Affairs and Security Policy, as well as the establishment of the European External Action Service, it will take considerable time before the EU is likely to speak with one voice and in a coherent manner. Individual member states' interests still seem to interfere with commonly agreed EU positions. From the perspective of many Africans there is a major gap between what the EU preaches in strong value-driven discourses and strategies and what it delivers in practice. The EU's political dialogue with Africa is often perceived by many Africans as patronizing and quite ambiguous, a relationship marked by double standards instead of a partnership of equals (African Union, 2006). Obviously, there are still much ground to be grasp in the relationship of both regions as major differences still exist between the two in crucial issues such as development level and agenda, technology, migration, governance, human rights and many more. All this are posing serious challenges not only to EU-AU relations but also their cooperation on global arena to enhance the global integration (Coleman \&Underhill, 1998).

\section{CONCLUSIONS: EUROPEAN UNION, WHAT LESSONS FOR AFRICAN UNION?}

The EU's experience-including, not least, the ongoing Eurozone crisis -- offers plenty of lessons that could help the EAC replicate the EU's successes while avoiding its troubles. Economically, the evidence suggests that African countries should vigorously integrate their markets but move cautiously regarding a common currency. Politically, they should focus intensely on accountability for democratic practices, though progress on this front will be more difficult than in the economic sphere.

With its 54 fully-recognized sovereign states, Africa is one of the world's most populous continents, with more than one billion people. Having struggled to free itself from colonialism, Africa now seeks to create a new image through global trade, and most importantly through intra-Africa trade, with Africa's trading blocs playing a key role. If this continues, the continent's economy is forecasted to grow by more than 10 percent annually in the next 10 years. (Adedeji, 1995).

The Euro zone debt crisis can teach Africa significant lessons about increasing trade within Africa itself. The European integration model can be used by Africa in establishing a one- currency continent. Currently there are great speculations on formation within Southern African Development Community (SADC) countries to allow access and usage of the same currency. The South African rand in Zimbabwe, Lesotho, Swaziland, and Namibia is an example of this type of slow currency integration.

Some of the significant things that have made the European integration a success are the treaties, laws, and regulations that govern the economic union. For Africa to create laws and regulations that promote free trade between its countries, key trading blocs like the African Union, SADC, the 
Economic Community of West African States, the Common Market for Eastern and Southern Africa, and the Southern African Customs Union will have to constructively collaborate to review and establish new rules and regulations encouraging increased intra-African trade. They must also ensure that African countries minimize raising household and government debt levels, trade imbalances, structural system problems, and monetary policy inflexibility, which are the major causes of the current EU economic meltdown.

To ensure that intra-regional trade is beneficial, African countries will have to focus on exporting products that gives comparative advantage. For example, countries such as Botswana and the Democratic Republic of Congo are principal exporters of copper and diamonds, and thus can increase the export of these goods to other countries. Africa is still a large exporter of agricultural products, but imports many of its manufactured products. The growth of the continent can be better achieved through diversified economic structures. Though it is in a recession, the European economy is still strong, diversified, and has competitive industrial structures. Its manufacturing sector represents one out of every four private-sector jobs.

Just like within the euro zone, African leaders are struggling with regional integration for supporting the continent's economic development. To increase trade between African countries, regional economic integration of free trade must be established between the countries. The African Union, working with all the continents six key trading blocs, must spearhead Africa's development and integration. The Program for Infrastructure Development in Africa is playing a crucial role in connecting, integrating and transforming Africa's infrastructure in transport, energy, ICT, and trans-boundary water networks. The program will spend close to $\$ 80$ billion by 2020 in developing Africa's infrastructure (Farrands, 2000).

To unleash intra-African trade and for Africa to take its rightful place in the global arena, the continent needs strong political leadership and policies. Africa is the least integrated continent in the world, with low levels intraregional economic exchanges and the smallest share of global trade. Africa's governments and heads of state need to serve as champions. They must set the tone, keep the momentum alive, and provide critical national leadership by working together and showing an unwavering commitment to integrated policies, projects, and goals that will take Africa to the next level (Round, 2007).

As the EU struggles to emerge from crisis, African leaders are demonstrating that the case for integration remains upper most in their mind (African Union, 2006). So, if the African Union can learn from the European Union's history; the people of Africa could enjoy enduring political stability and improved economic opportunities. With this, Africa can therefore become a more important business and security partner for the European Union and other big global economic powers. But before this will happen, 'African Lions' must be ready to have their day in the sun' especially through a common platform to be provided by the African Union. The AU must urgently start generating genuine ideas towards real integration that could offer sustainable development on the continent by building national economies and directly impacting on daily existence of average Africans. Through the platform of AU, Africa must start to re-negotiate its relationship with the international economy such that the new-found love with China and the interregional affiliation between AU and EU will not turn out to the rat race or a new scramble for economic soul of Africa by two global powers! And the power of renegotiation actually depends on how well African 
Leaders can localize and internalize development opportunities offered by globalization through a well-managed and inclusive regionalism.

\section{REFERENCES}

Adedeji, A. (1995). “An Alternative for Africa,” In Larry Diamond and Marc F. Plattner (Ed.) Economic Reform and Democracy, Baltimore, MD: The John Hopkins University Press.

African Forum for Strategic Thinking, (2002). Sustainable Development, Governance and Globalization: African Perspective. Nairobi: Heinrich Boll Foundation.

Africa and EU Partnership Organization (2007) “Africa-EU Joint Strategy in 2007.” Retrieved on March 12, 2014, from www.africa-eu-partnership.org.

African Union, (2006). Study on An African Union Government: Towards the United States of Africa Addis Ababa, Ethiopia.

African Union, "Profile: Organization of African Unity/African Union" and "Achievements and Challenges of The African Union. "Retrieved on March 12, 2014, from the African Union website: www.africaunion.org.

Aina, T. (1996). Globalization and social policy in Africa. CODESRIA Working Paper No.6. Dakar: CODESRIA, 1996.

Ake, C. (1992). The New World Order: A View from the South. Port Harcourt: Centre for Advanced Social Science.

Amin, S. (1972). "Underdevelopment and Dependence in Black Africa," Journal of Modern African Studies, 10(4).

Amin,S. (1976).Unequal Development: An Essay on the Social Formations of Peripheral Capitalism. New York: Monthly Review Press.

Anonymous, (2005, May 9). "Leaders mourn Soviet wartime dead" BBC News. AWAKE! (2000). "A United Europe-Why Would it matter? Unity in the Making."Brooklyn, NY.

Babarinde,O. (2007). "The European Union as a Model for the African Union: The Limits of Imitation." A Paper Presentation in Montreal, Canada

Barany,A. (2010). "The Four Theories of Globalization," Issues 5 (3): 2-10.

Barrett, P. (2004). Science and Theology Since Copernicus: The Search for Understanding, USA Continuum International Publishing Group. pp. 14-18.

BBC News, (2007, 8 February) "EU job centers to target Africans." Retrieved on March 10, 2014 from the British Broadcasting Corporation. Website:

http:news.bbc.co.uk/hi/Africa/6341487.

Brown, W. (2002). The European Union and Africa: The Restructuring of North--South Relations. London, The Library of International Relations.

Brzezinski, Z. (1995). Former head of the Trilateral Commission, speaking at the State of the World Forum. Retrieved on March 10, from the Wikipedia. Website: http://en.wikipedia.org/wiki/Zbigniew_Brzezinski.

Burckhardt, J. (1990). The Civilization of the Renaissance in Italy (translation by S.G.C Middlemore, London, England: Penguin Books.

Cilliers, J. (2008). "The African Standby Force. An Update on Progress" Institute for Security Studies, South Africa.

Coleman, W.D. \& Underhill, G.D. (2004). Regionalism and Global Economic Integration: Europe, Asia and the Americas, New York, Routledge. 
Craig, G.A. (1970). Europe Since 1815, (3rd Edition), USA, Rinehart and Winston. Farrands, C. (2000). "Technology and the Technical Management of Human Resources:

Prospects for SubSaharan African Development into the New Millennium," in Bakut,B. and Sagarika Dutt,S.(2000) (Ed.) Africa At The Millennium: An Agenda for Mature Development. Bakingstoke, Palgrave.

Frank, A.G. (1993). "Marketing Democracy in an Undemocratic Market”, in B. Gills et al., (Ed.), Low Intensity Democracy: Political Power in the New World Order (pp34-48). London: Pluto Press.

Fukuyama, F. (1992). The End of History and the Last Man. New York, The Free Press.

Griffin, K. \& Khan, A.R. (1992). Globalization \& The Developing World: An Essay on the International Dimensions of Development in the Post-Cold War Era, Geneva: UNRISD.

Haas, E.B. (1971). "The Study of Regional Integration; Reflections on the Joy and Anguish of Pretherizing” in Lindberg, L.N. \& S.A Scheingold, Regional Integration: Theory and Research. Massachusetts, Harvard Press.

Held, D. \& McGrew, A. (1997). “Globalization," Krieger, J. The Oxford Companion to the Politics of the World, (2nd. Edition), Oxford: Oxford University Press.

Hoogvelt, H. (1997). Globalization and the Postcolonial World: The New Political Economy of Development. London: Macmillan Press Ltd.

Huntington, S.P. (1996). The Clash of Civilization and the Remaking of the World Order. New York, Simon \& Schuster.

Ian, T. (2005). “NEPAD” - Toward Africa's Development or Another False Start? London: Lyne Rienner Publishers Inc.

Jinadu, L. A. (2000). “Globalization and the New Partnership: An African Perspective.”, In Guy Lachapelle and Trent, J (Ed..), Globalization, Governance and Identity: The Emergence of New Partnerships. Montréal : Les Presses de 1'Universitaire de Montréal.

Lachapelle, G. \& Trent, J. (Ed.). (2002). Globalization, Governance and Identity: The Emergence of New Partnerships. Montreal: Les Presses de l'Universite d e Montreal.

Levey, M. (1971). High Renaissance, London, Penguin Books.

Lisk, F. (2010).“The African Union after 10 years: Successes and Challenges.” Retrieved on March 12, from Warwick University News center. Website: http://www2.warwick.ac.uk/newsandevents/expertcomment/the african_union/.

Niewyk, Donald L. Nicosia, Francis R.2000. The Columbia Guide to the Holocaust, Columbia University Press 2000, pp. 45-52.

Nkrumah, K. (1963). Africa Must Unite, New York: Praeger.

Ojo, O. D.K Omo, D.K.\& Zltete, C.M.B. (1985). African International Relations, London, Longman.

Oyugi, W. (2009). "African Union and European: A Comparative Analysis," in Said Adejumobi and Adebayo Olukoshi (Ed.) The African Union and New Strategies for Development in Africa., New York: Combria Press. Round, J.2007. Globalization, Growth, Inequality and Poverty in Africa: A Macroeconomic Perspective, WIDER Research Paper.

Rourke, J. T. (2003). International Politics on the World Stage, 9th Edition, USA, McGraw Hill. Rugumamu, S.M. (2005). Globalization demystified: Africa's possible development futures, Dares Salaam University Press Ltd.

Scott, J. (2005). Industrialism: A Dictionary of Sociology, Oxford, Oxford University Press. Sigler, J. (2010). "A Theory of Globalization. "Retrieved March 10, 2014 from http://www.crdi.ca/en/ev87930-201-1-DO TOPIC.htmlDocument(s). 
The European Communities (2007). Key Facts and Figures about Europe and Europeans.

Luxembourg: Office for Official Publications of the European Commission.

The European Union, (2010)"EU27 Member States granted citizenship to 696000 persons in

2008."Retrieved on March 12, 2014, from Eurostat. Website: http://epp.eurostat.ec.europa.

The United Nations Organization, "Security Council Authorises Deployment of United Nations-

African Union 'Hybrid' Peace Operation in Bid to Resolve Darfur Conflict." Retrieved on

March 12, 2014, from the United Nations information center. Website: www.un.org.

Unknown Author, "The European Union Debt Crisis: Lessons for Africa." Retrieved on March

12, 2014 from: http://www.trademarkea.com/the-european-union-debt-crisis-lessons-forafrica/

Wang, L. (2012) "New headquarters shows partnership entering era of hope: Ethiopia PM" China Daily.

William D. Coleman\& Underhill, G.D.1998. Regionalism and Global Economic Integration: Europe, Asia and the Americas. London: Routledge. 